\title{
Bones, Stones, and Monica ${ }^{1}$ Isola Sacra Revisited
}

Laurens E. Tacoma

For Henk Versnel, who taught me to cherish inconsistencies

Traditionally, studies of migration and mobility have relied to a large extent on the analysis of the thousands of epitaphs that have survived from the Roman world. The epigraphical evidence from the period of the Principate is abundant, but there are also reasons for caution. We are dependent on patterns of commemoration and self-representation. One major problem for the study of Roman migration through epigraphy is that identity was not necessarily expressed in ethnic terms: in many cases legal and social status were more important. Moreover, epitaphs offer static snapshots of what was by definition a dynamic process. In consequence, we have evidence of people who moved,

1 This paper is one of the by-products of a research project on Roman migration and labour conducted at Leiden University; I wish to thank the Netherlands Organisation for Scientific Research (NWO) for funding the Moving Romans project. The section on Augustine was presented in extended form at a seminar in Amsterdam in June 2015; the present paper at the Impact conference in Rome and at a seminar on Migration and mobility at Augsburg in Jan 2016. My thanks to the three audiences for offering helpful suggestions. Some of the discussion on the isotopes is taken from my monograph Moving Romans. Migration to Rome in the Principate (Oxford 2016), where a general discussion of sources for the study of migration can also be found, in chapter 1. Further reflections on the use of the epigraphic sources can be found in L.E. Tacoma and R.A. Tybout, 'Inscribing Syrian mobility in the Hellenistic and Roman period', in: A.J. Yoo and A. Zerbini, eds., A Home Away from Home. New Paths to the Study of Migration and Migrant Identities in the Eastern Mediterranean from the Roman Period to the Crusades (Farnham, forthcoming). 
but hardly ever can see how they moved, let alone what caused them to move. Motivation can hardly ever be inferred from such texts.

The dynamics of migration are in principle better visible in literary sources. Here we can see the itineraries of individuals, and what decisions lay behind movements. At the same time, it is hardly a secret that an analysis of such texts suffers from all the problems traditionally associated with ancient literary sources: they cover the elite only, they may be embedded in moral discourses, and they might privilege the exceptional over the normal.

In recent years, written sources have been supplemented by findings from bio-archaeological studies. In particular the analysis of isotopes in human bones and teeth has been shown to hold great potential. By comparing ratios of stable isotopes in teeth and bones within a sample, it is possible to distinguish between immigrants and locals.

It is obvious that these three types of sources can contribute significantly to our understanding of Roman migration patterns. But the question of how these findings relate to each other has not been addressed fully. That is the aim of the present article.

There is one place in the Roman world for which it is possible to make a direct comparison between the three different source types. This is the Isola Sacra necropolis at Ostia/Portus, the harbour city of Rome. Its skeletons have been subjected to isotopic research. Isola Sacra is also exceptionally well documented epigraphically and archaeologically. Moreover, Ostia figures prominently in what is arguably the fullest migration account to survive from the Roman period, Augustine's Confessiones. As I will argue, the mismatch between the three types of sources is relatively large. They each tell a rather different story. Each of them also has particular problems of interpretation. At the same time, there is no reason to privilege any of the three types, and this raises major methodological problems about the handling of the evidence.

Over the last two decades bio-archaeologists have subjected human skeletons to all types of analysis. The best results thus far have been achieved by the analysis of stable isotopes from teeth and bones. Isotopic analysis is based on the principle that, during the growth of teeth and bones, the food and water that are consumed produce a chemical profile that is geographically specific. By comparing ratios of stable oxygen or strontium (or other) isotopes in teeth and bones within a sample, it is possible to establish the extent of homogeneity 
within such a sample. Individuals with a markedly different chemical profile are assumed to have grown up elsewhere and hence to be immigrants. ${ }^{2}$

Isotopic analysis of skeletal remains has a number of advantages. It helps to identify migrants that remain otherwise invisible in the burial record. ${ }^{3}$ It also quite conveniently uses a definition of migration that is (implicitly) also used among scholars who focus on written sources, and which is also used here: Migration is defined as the movement of persons who change their residence from one place to another on a permanent or semi-permanent basis. That is, it focuses on first-generation migrants, independent of legal or social status. ${ }^{4}$ Thirdly, and lastly, isotopic analysis is capable of producing figures for total numbers of migrants within the population under consideration. In that sense it offers the type of quantitative evidence that is so desperately needed.

While the potential of stable isotope analysis is clear, it would be naive to expect too much of it and it would be a mistake to take it as hard factual evidence that speaks for itself. It does not present to us the reference population against which we can judge in what directions the written sources are biased. Apart from technical problems in the analyses (some incidentally quite formidable), major interpretative issues are raised.

These issues have surfaced in a small debate over the findings from Isola Sacra at Ostia/Portus. In 2007 a research team led by Tracey Prowse published a pioneering isotopic analysis of oxygen-stable isotope ratios of series of teeth in a sample of 61 individuals from Isola Sacra in Ostia. It showed a substantial number of migrants among the population. Among the 61 individuals, she found 20 immigrants (33 per cent). ${ }^{5}$ As there were a substantial number

2 T.L. Prowse, 'Isotopes and mobility in the ancient Roman world', in L. de Ligt and L.E. Tacoma, eds., Migration and Mobility in the Early Roman Empire (Leiden 2016), 205-233 for explanation and a very useful survey of the rapidly expanding literature.

3 This is of real importance, as graves and grave-goods in the Roman world are very often ethnically unspecific. For example in the cemetery of Vagnari in Puglia, studied by T.L. Prowse, J.L. Barta, T.E. von Hunnius, and A.M. Small, 'Stable isotope and mitochondrial DNA evidence for geographic origins on a Roman estate at Vagnari (Italy)', in H. Eckardt, ed., Roman Diasporas. Archaeological Approaches to Mobility and Diversity in the Roman Empire. Journal of Roman Archaeology Supplement 78 (Portsmouth 2010), 176: "Evidence from the burials themselves (burial type, grave goods) does not provide a clear indication of differential burial treatment for foreigners versus locals."

4 Tacoma 2016, op. cit. (n. 1), chapter 2 for further discussion.

5 T.L. Prowse, H.P. Schwarcz, P. Garnsey, M. Knyf, R. Macchiarelli, and L. Bondioli, 'Isotopic evidence for age-related immigration to imperial Rome', American Journal of Physical Anthropology 132 (2007), 510-519. In what follows, I use the modified 'local range' established by K. Killgrove, Migration and Mobility in Imperial Rome (diss. Chapel Hill 2010), 249, which leads to slight adaptations of the original figures of Prowse et al. 
of women and children among them, Prowse and her team argued that the traditional male-based migration model, in which it is assumed that migrants are primarily young adult males, was in need of revision. Instead, people moved as families. ${ }^{6}$

In 2010, however, the study by Prowse was criticised by Christer Bruun on several counts. ${ }^{7}$ Bruun argued that the presence of women and children among the immigrants is open to multiple interpretations. While it is certainly feasible that children moved as part of a family together with their parents, they could also have been brought as slaves or, in the case of women, as brides; they may even have moved independently. Depending on their exact age and economic position they may also be classified as 'sub-adults' rather than as children. There is no need to repeat here all of Bruun's arguments and the further responses to his criticisms, which are partly of a technical nature. We may focus here on four relatively simple points.

Firstly, sample size. Prowse used 61 skeletons, on an estimated total number of 2,00o excavated skeletons (of which c.1,00o are well-catalogued). It must be clear that the dangers of extrapolating the figures to the total population of Ostia, let alone to the wider world, are great indeed: this is a world of smallnumber statistics. Small changes in values immediately affect outcomes. A figure of 33 per cent of immigrants may be suggestive for general levels of immigration, but surely should not be used as the basis for major claims.

Secondly, the outcome of the technical analysis is not as straightforward as one would think: foreignness turns out to be a matter of degree rather than something absolute. A sample produces a spectrum of isotopic values whose outliers are considered to be immigrants, but this leaves room for a grey zone of ambiguous cases. Again, small changes in what is considered the local range have an immediate impact on the percentages of immigrants.

Thirdly, the method is much better at identifying outsiders within a local population than at establishing their origin. Far too little is known about the geological and hydrological profiles of the Roman world to identify geographical origin with any reasonable degree of certainty. So, Prowse mentioned as

6 Prowse et al. 2007, op. cit. (n. 5), e.g. 510 (abstract): “This study demonstrates that migration was not limited to predominantly single adult males, as suggested by historical sources, but rather a complex phenomenon involving families."

7 C. Bruun, 'Water, oxygen isotopes, and immigration to Ostia-Portus', Journal of Roman Archaeology 23 (2010) 109-132, with response by K. Killgrove, "Response to C. Bruun, "Water, oxygen and immigration to Ostia-Portus", Journal of Roman Archaeology 23 (2010), 133-136. The debate is unresolved; see for a second round C. Bruun, 'Tracing familial mobility: female and child migrants in the Roman West', in L. de Ligt and L.E. Tacoma, eds., Migration and Mobility in the Early Roman Empire (Leiden 2016), 176-204 with reiteration of the major criticisms, and Prowse 2016 op. cit. (n. 2) for a defence. 
possible origins of the immigrants buried in Isola Sacra the area "north of the Italian landmass", "the foothills and heights of the Apennine Mountains" and "the Iberian Peninsula or Greece", among others. ${ }^{8}$

Lastly, the logic of the interpretation of the data on which the claim for child migration is based, is problematic. The analysis used oxygen stable isotopes from first and third molars to determine local and non-local origin. The first molar is formed before birth and completed around age 2.5-3.0; the third starts to form at age 7-12 and is completed at age 10-17.5. In an ingenious argument, Prowse used the time gap between the first and the third molar to determine the moment of migration. People with a non-local first molar and a local third molar can be thought to have migrated before the completion of the third molar, that is, in their youth; people with non-local first and non-local third molars, to have migrated as adults. The analysis of the Isola Sacra data found among 61 individuals 13 child immigrants, and seven adult immigrants (see Table 1, rows 1-3). This produced a remarkable pattern, with almost twice as many children as adult immigrants, and this in turn led to the argument about the importance of family migration.

However, what on closer inspection also emerges from the data, is that there is an additional group whose migrant history is less easy to explain: those with a local first molar and non-local third molar (see Table 1, row 4). This group consists of eight persons. According to the logic of the argument, they must have been born in Ostia, moved elsewhere in their teens (before the formation of the third molar started, at age 12 at the latest, but possibly as early as age 7), and then after their third molar was completed they returned to Ostia, where they subsequently died. Although it is certainly possible to come up with scenarios, it is very difficult to think of a coherent pattern that can explain such movements. It is disconcerting that this group was ignored in the original publication of the research, particularly in view of the claims about the importance of child migration. In fact, and somewhat strangely, this group of young 'remigrants' was silently subsumed under the local population. The point would be of minor academic interest, were it not for the fact that the whole claim of child migration rests precisely on these third molar data. Part of these data were thus used to make the claim for child migration, but part of it was ignored for the group that was less easy to interpret, the 'remigrants'. That seems inadmissible. If the third molar data are left out of consideration, much of the case for child migration is lost: we are left with 20 immigrants who came to Ostia at an unknown point in time after their first molar had formed.

8 Prowse et al. 2007, op. cit. (n. 5), 517-518. 
TABLE $8.1 \quad$ Isola Sacra data (source: Prowse et al. 2007, op. cit. (n. 5), with Killgrove 2010, op. cit. (n. 5), 249)

\begin{tabular}{llll}
\hline Mi & M3 & N & Interpretation \\
\hline Local & Local & 33 & locals \\
Non-local & Local & 13 & child immigrants \\
Non-local & Non-local & 7 & adult immigrants \\
Local & Non-local & 8 & 'remigrants'?
\end{tabular}

Prowse's study certainly deserves credit for its pioneering efforts. However, it should also be clear that given the present state of the evidence, large claims cannot be based on the isotopic analysis alone. The evidence is certainly not as hard as ancient historians might take it to be. If Prowse's claim for family migration is rejected, one is easily left with the impression that the isotopic study has merely reinstated something that could have been assumed on a priori grounds - a high level of immigration is a natural characteristic of harbour cities-and whose particulars are better documented by the abundant epigraphic evidence that survives from Ostia.

\section{$3 \quad$ Stones}

In the debate on the work of Prowse, it has not been fully taken into account that the Isola Sacra necropolis is itself exceptionally well documented epigraphically and archaeologically. ${ }^{9}$ It is therefore possible to compare in a much more direct fashion the findings from isotopic studies with those from epitaphs and literary texts. ${ }^{10}$ The inscriptions and tombs allow for the creation of

$9 \quad$ The possibility was mentioned by Bruun 2010, op. cit. (n. 7), but it seems no coincidence that the epigraphic examples that he cites himself come from other areas of Ostia. It is discussed briefly by Prowse 2016 op. cit. (n. 2), 216-217: she and her team refrained from analysis partly on the grounds that "the epigraphic record only records the origins of individuals in a small number of cases." That is exactly the point.

10 Though not in the most direct way. As the exact provenance of the skeletons is undocumented, it is not possible to connect particular tombs and inscriptions with particular skeletons. See Prowse 2016 op. cit. (n. 2), 217 for some remarks: after the excavations were completed, skeletons were apparently dumped back in the graves, but not necessarily their own. 
a social profile of the population that was buried at Isola Sacra, and permit an analysis of how mobility was inscribed.

In what follows, I confine myself for practical reasons to the area of the so-called 100 tombs, excavated mainly in $1930 .^{11}$ The area presents a coherent corpus. It forms one of the best examples of an ancient Grabestrasse with wellpreserved tombs and many inscriptions and reliefs still in situ. The tombs are well described, and the inscriptions have been edited twice. ${ }^{12}$ In total there are 114 Latin and 6 Greek inscriptions. ${ }^{13}$

Although the inscriptions have no internal dates, and some ambiguous cases remain, the chronology is relatively clear. Most tombs have been well dated on stylistic grounds, on the basis of brick stamps or on the basis of onomastic criteria in the inscriptions. The majority of tombs stem from the middle of the second to the early third century and thus present a relatively small slice of the imperial period. ${ }^{14}$ The chronology is of importance, for the 100-tomb graveyard is one of the best witnesses to the shift from cremation to inhumation that took place in this period. Some tombs contain solely cremation burials, others solely inhumation graves, and some a mixture of both; in addition, the inscriptions occasionally refer to either or both burial practices. ${ }^{15}$ The shift

11 This includes some additional finds from the same area made subsequently. Note that the territory comprised by Isola Sacra is much larger than the 100-tomb area alone, though excavations have mostly taken place in its vicinity. There are also tombs and inscriptions found outside the 100-tomb area, or inscriptions that could not be related to a particular tomb, both in earlier and in subsequent excavations. Although some of these concern larger family tombs, the general picture that emerges from these other tombs seems very similar to what can be gathered from the 100-tomb area.

12 Inscriptions: H. Thylander, Inscriptions du port d'Ostie (Lund 1952) (IPOstie); A. Helttula et al., Le iscrizioni sepolcrali latine nell'Isola sacra (Rome 2007) (ISIS). The new edition offers a more complete series of texts (despite the titleincluding also the Greek ones), and improved readings and dating, and also has a very full series of extremely useful indices. However, the later edition does not completely replace the earlier one as Thylander offered some historical commentary and provided translations. The tombs themselves are described in the ISIS publication, but full photographic documentation can be found at http:// www.ostia-antica.org/valkvisuals/html/tombsintro.htm (last consulted February 2016).

13 Latin: ISIS 21 = IPOstie A13 (tomb 1) - ISIS 133 = IPOstie A122 (tomb 10o); Greek: ISIS $15^{\text {gr }}$ (tomb 6a) - ISIS $20^{\text {gr }}$ (tomb 65).

14 There is one early fourth-century Christian grave: ISIS $42=$ IPOstie A285 (tomb 38), but this concerns the reuse of an older tomb. At the other end of the chronological spectrum, ISIS 50 = IPOstie A6o (tomb 49) may perhaps date to the second half of the first century, but a Trajanic date is also possible.

15 For cineres, see ISIS 53 = IPOstie A75 (tomb 51); for ollae, see ISIS 124 = IPOstie A124 (tomb 94); for sarcophagi, see e.g. ISIS 29 = IPOstie A9o (tomb 16), with many more examples 
to inhumation incidentally strongly suggests that the skeletons analysed by Prowse date from the early third century rather than the general period of the first to third centuries AD.

Obviously, tombs and their inscriptions served primarily to commemorate the dead. In doing so, the emphasis was on communication between the dead and the living, between commemorated and commemorator. ${ }^{16}$ But, as is well known, communication was also directed at third parties, at the outside world of fellow citizens of Ostia and Portus. The people who built the monuments and erected the inscriptions were not plainly documenting who they were, but were portraying who they wanted to be, and in that sense the tombs are not a mere mirror of urban society. The people who made them engaged actively in self-representation. ${ }^{17}$

The social profile of the people buried in the tombs covers a significant part of the urban population. There are no persons who belonged to the urban elite proper (no decurions, no magistrates, no high-ranking administrators), but the sub-elite strata seem well represented. In one case an occupation is mentioned, that of a tabellarius. There are some occupational reliefs depicting among others a baker, a midwife, and a surgeon, and there are also some hints at trading activities. ${ }^{18}$

The focus in the inscriptions is very much on the family. Just as elsewhere in the Roman world, the families that are buried in the tombs are predominantly nuclear: they consist of a husband, wife, and children. The family is small, and covers a limited number of generations. Only rarely do we find tombs with three or more generations. ${ }^{19}$

given in the ISIS-index, Helttula et al., op. cit. (n. 12), 397, and the remarkable prohibition of ISIS 106-107: ita ne in hoc monumento sarcophagum inferatur. ISIS $27=$ IPOstie A245 (tomb 11) mentions corpus sibe ossa. ISIS $141=$ IPOstie A256 (tomb 102) mentions ollae and sarcophagi.

16 V.M. Hope, Roman Death. The Dying and the Dead in Ancient Rome (London and New York 2009), esp. 151-181.

17 Obviously, in some cases the claims concerned the deceased relatives rather than the persons who commemorated them, so the term 'self-representation' is not always strictly appropriate. But note that many of the tombs were built inter vivos.

ISIS 127 = IPOstie A279 (tomb 96), for a tabellarius, an imperial freedman. For reliefs, see e.g. tomb 78 (sailor and baker), tomb 90 (a sailer and ostiaria), tomb 100 (a midwife and surgeon).

19 Tomb 4 a contains different persons belonging to the same family. Tomb $75^{-76}$ is a very large tomb with a complex structure involving three families; it was eventually split into two separate tombs. 
The family is small, but the familia is not. One of the most striking aspects of the Isola Sacra tombs is the prevalence of slavery and the multiplicity of forms in which slavery was inscribed. Many of the cremation tombs contain a remarkable number of niches set into the walls. Given the small size of the families buried in such tombs, and the fact that most tombs seem to have held only the remains of a very limited number of generations, the implication is that at sub-elite levels the extent of slavery was large-perhaps larger than is normally assumed..$^{20}$ The conventional phrase that the tomb also provides for the burial of 'freedmen, freedwomen, and their descendants' suggests that former slaves remained close to their owner. Slaves also appear in other capacities. There are a significant number of commemorations of deceased slaves by their owners, but also by fathers or mothers with single names and thus presumably slaves who commemorated their deceased slave children. In addition, slaves and liberti set up monuments for their owners and former owners, and there are even some liberti who set up monuments for themselves while including their owners, in a nice reversal of patronage relations. There are also a significant number of imperial slaves and freedmen. ${ }^{21}$

Most of the persons mentioned by name in the inscriptions sport a tria nomina (or duo nomina in the case of women), indicating Roman citizenship. As filiation is often lacking, it remains uncertain whether we are dealing with freedmen or freeborn. ${ }^{22}$ In a number of cases the cognomina are suggestive of slave descent, and there are some cases where the fact that husband and wife share the same gentilicium reveals their former slave status. ${ }^{23}$ There are also

20 As tombs may have been split between different owners, the number of niches cannot be used as a direct indicator for sizes of slave familiae. The figures mentioned in some inscriptions are probably more indicative. See ISIS 116 = IPOstie A47 (tomb 9o) for 9 sarcophagi for husband and wife and their freedmen and descendants; ISIS 124 = IPOstie A124 (tomb 94) for a man buying part of a tomb, comprising 14 ollae; ISIS 29 = IPOstie A9o (tomb 16) for 12 sarcophagi. For archaeological data on numbers of inhumation graves, see B. Borg, Crisis and Ambition: Tombs and Burial Customs in Third-Century CE Rome (Oxford 2013), 22-23; note that one of the largest ones could house 150 sarcophagi (tomb 34). ISIS 50 = IPOstie A6o (tomb 49); ISIS 87 = IPOstie A261 (tomb 75); ISIS 117 = IPOstie A104 (tomb 90); ISIS 119 = IPOstie A77 (tomb 91); ISIS 123 = IPOstie A96 (tomb 94); ISIS 125, ISIS 127 = IPOstie A279 (tomb 96).

For a (rare) counter example with filiation and tribus, see ISIS 32-33 = IPOstie A249-A250 (tomb 19).

23 E.g. ISIS $120=$ IPOstie A121 (tomb 92) for a family of freedmen; the dedicator acting together with a freedman of his own. Conversely, the most likely explanation of the fact that in ISIS $128=$ IPOstie A146 and ISIS $129=$ IPOstie A147 (tomb 97) the mother and two sons each have different gentilicia is that they were former slaves of different owners. 
some inscriptions where the references to col- or conliberti explicates status. ${ }^{24}$ It thus seems not far-fetched to suppose that a significant proportion of the Roman citizens of the 100-tomb area had acquired their citizenship through manumission.

Although the tombs belong to the sub-elite population, a significant number of them clearly give a sense of affluence. The simple fact that plots are bought, sold, ${ }^{25}$ and partitioned ${ }^{26}$ suggests a lively market in burial plots, implying at least a modicum of wealth. More direct evidence for wealth is provided by tomb size (both physical tomb size and the sizes that are mentioned in inscriptions): some of the tombs were remarkably large. ${ }^{27}$

The graves not only convey a sense of affluence, but on closer inspection also show significant variation in wealth. The variation in size is marked, and certainly not all tombs are chamber tombs. Some graves are in fact rather poor. A couple of them are built at the back (and out of sight) of the larger tombs. At the lower end of the social scale, there are also graves consisting of little more than a simple grave marker like an amphora, slotted into the available space. ${ }^{28}$

The social profile of the people buried at Isola Sacra is perhaps not particularly surprising, and fits well with the general picture of urban society of Roman Italy. It is rather the completeness with which it is documented that is remarkable. This makes it all the more striking that migration and mobility are not very well inscribed. Among the 120 inscriptions there is exactly one explicit reference to a migrant: ${ }^{29}$

$\mathrm{D}$ (is) $\mathrm{M}$ (anibus) / C(ai) Annaei Attici Pict(onis) / ex Aquitanica pro(vincia), def(uncti) / ann(orum) XXXVII, domestici / eius ponendum curarunt

24 ISIS 26 = IPOstie A244 (tomb 11); ISIS 79 = IPOstie A238 (tomb 71); cf. ISIS 78 = IPOstie A239 (tomb 70).

25 E.g. in ISIS 93=IPOstie A17 (tomb 75); ISIS 94 (tomb 75); ISIS $113=$ IPOstie A180 (tomb 89).

26 ISIS 51 = IPOstie A64 (tomb 50) mentioning ex portionibus; ISIS 92.

27 The measurements written in inscriptions range from $10 \times 10($ ISIS 37, 55) to $40 \times 40$ Roman feet (ISIS 82), see ISIS index, Helttula et al., op. cit. (n. 12), 391-392; this seems in line with the range of the physical remains. Not only is plot size important, but also tomb height, as many tombs contained a second floor. Tombs could be shared between different owners, but that generally seems to be a subsequent development.

28 Hope 2009, op. cit. (n. 16), 158.

29 ISIS 21 = IPOstie A.13 (tomb 1); with L. Wierschowski, Fremde in Gallien- 'Gallier' in der Fremde. Die epigraphisch bezeugte Mobilität in, von und nach Gallien vom 1. bis 3. Jh. n.Chr. (Texte-Übersetzungen-Kommentare). Historia Einzelschriften 159 (Stuttgart 2001), 15, nr. 3. A second case of an ethnicon may be hidden in the end of the name of Lucius Malius Natalis $C_{+}[---]$in ISIS $34=$ IPOstie $\mathrm{Al}_{11}$ (tomb 50), but its reading is extremely uncertain. 
To the gods of the underworld of C. Annaeus Atticus, Pictone from the province Aquitania, who died when he was 37. His servants have taken care [that this monument] was erected.

The epitaph mentions a freeborn or freed Roman citizen named Caius Annaeus Atticus, who died in his thirties. He was described as belonging to the Pictones, a people in Aquitania, and to come from the province of that name. He was commemorated by his domestici, presumably his servants. The fact that he was buried in Ostia may suggest that he migrated as a trader; the fact that he was buried there and had servants to bury him may suggest he had settled there. All this is of course rather speculative, and the fact that no named commemorators are mentioned and that he appears as an adult male without family, may just as well imply that he died en route.

Perhaps the most interesting aspect of this migrant is not the text of his inscription, but the form of his tomb. It is relatively small, and it has a peculiar shape: a pyramid. It has repeatedly been emphasized over the past decades that Aegyptiaca have little to do with the presence of Egyptians. ${ }^{30}$ There are some more tombs with pyramid shapes, but the fact that this one was made for a migrant from Gaul is an explicit demonstration of that fact.

There are, to be sure, more hints that point towards mobility apart from this one inscription that explicitly mentions migration. However, they are suggestive rather than that they really prove that mobility took place. ${ }^{31}$

The first and most obvious of these hints is the wide prevalence of slaves. In itself slavery need not imply immigration, as many slaves may have been born in Ostia. As Scheidel has argued on general grounds, the large slave populations that we find in the Roman Principate can only have been sustained by a significant amount of self-reproduction. ${ }^{32}$ Many of the slaves of Ostia are thus likely to have been vernae. On the other hand, the openness of Ostia as a harbour city makes it hard to believe that at least some slaves did not come from elsewhere.

$30 \quad$ See M.E.J.J. van Aerde, Egypt and the Augustan Cultural Revolution. An Interpretative Archaeological Overview (diss. Leiden 2015).

31 In addition to the cases discussed below, there are with different degrees of probability also some cases of peregrines: ISIS 60 (tomb 55a) dedicated Alypo Ionici f(ilio); possibly also ISIS $20^{\mathrm{gr}}$ (tomb 65); ISIS 81 = IPOstie A218 (tomb 74), though these could also concern slaves. Note that such peregrines need not be first-generation migrants.

32 W. Scheidel, 'Quantifying the sources of slaves in the Early Roman Empire', Journal of Roman Studies 87 (1997), 156-169, with some further comments in Tacoma 2016 op. cit. (n. 1), chapter 2. 
A second hint for migration and mobility is provided by language use. Some inscriptions are written in a Latin that seems less than perfect, suggesting the dedicator had a different first language. ${ }^{33}$ In addition, there are six Greek texts. ${ }^{34}$ Some of these are certainly suggestive of outsider origin. Most of the Greek inscriptions show Latin influence (for example in the use of formulae) and the tombs in which the Greek inscriptions appear often also included Latin inscriptions, pointing to more indirect forms of linguistic interaction. ${ }^{35}$ These patterns conform closely to those analysed by Adams in his study on bilingualism in the Roman world. Yet Adams also shows how complex language choices could be, and his central point is that language use is primarily an expression of identity and a sense of belonging rather than a direct pointer to origin. ${ }^{36}$

Lastly, there is some evidence from onomastics. Some cognomina carry strong hints of outsider origin. For example, there is a Malchion, a Semitic name often found among slaves. ${ }^{37}$ But that also immediately points to a problem. Most of such names belong to slaves or freedmen, and decades of scholarship have made clear how complex naming patterns are in their case.

It is not my aim to argue these hints away. In fact, it is surely possible to use a maximising rather than a minimising approach in trying to detect migrants. However, if the strict criteria are employed that epigraphers normally-and with good reason-employ in the study of migration, ${ }^{38}$ the evidence for migration at Isola Sacra is rather meagre. It is confined to exactly one case among 120 inscriptions. Perhaps this is not particularly surprising if we take epitaphs as expressions of belonging. The dynamics were social rather than geographical: people claimed a place in the urban fabric. However, the contrast with the

33 E.g. ISIS 29 = IPOstie A9o (tomb 16).

34 ISIS $15^{\mathrm{gr}}-20^{\mathrm{gr}}$.

35 Thus, tomb 43 contains not only the Greek ISIS 18gr (with harbour mosaic), but also the Latin ISIS 48 = IPOstie A314, which refers to two persons with the gentilicium Ostiensis, probably former public slaves of Ostia. Borg 2013, op. cit. (n. 20), 22-23 suggests the tomb may perhaps have belonged to "an association of people involved in the public administration of the ports"; this is certainly possible, but it seems just one out of many possibilities.

36 J.N. Adams, Bilingualism and the Latin Language (Cambridge 2003).

37 ISIS 49 = IPOstie A212, for a woman with duo nomina. Further e.g. Vetronia P(ubli) lib(erta) Naphame in ISIS $99=$ IPOstie A276 (tomb 82); Naphame is a Punic name, attested in Rome in $C I L$ 6. 22867 .

38 For a balanced discussion of criteria, see e.g. L. Wierschowski, Die regionale Mobilität in Gallien nach den Inschriften des 1. bis 3. Jahrhunderts n. Chr. Quantitative Studien zur sozial- und wirtschaftsgeschichte der westlichen Provinzen des römischen Reiches. Historia Einzelschriften 91 (Stuttgart 1995), 24-29. 
picture sketched by Prowse is marked. Whatever may be thought of isotopic research, the idea that epigraphy somehow documents mobility and migration better seems difficult to maintain.

4 Monica

The dynamics of migration are in principle better visible in literary sources. One text merits much fuller analysis than it has received thus far: Augustine's Confessiones. ${ }^{39}$ It presents what is arguably the fullest migration account to survive from the Roman period. Although the text is late, it presents a possible model that may be of help in understanding Roman patterns of migration in general. It is, in fact, in many respects unique. It presents in the form of a first-person narrative details of Augustine's movements and that of his mother Monica during the period when he pursued a worldly career. Because Augustine painstakingly if not obsessively reflects on his past life, ${ }^{40}$ we also learn much about the social context of his movements.

39 The possibilities that the Confessiones offer for the understanding of Roman mobility studies have not gone completely unnoticed. D. Noy, Foreigners at Rome. Citizens and Strangers (London 2000), 85-87 mentioned Augustine's case as the only case in the whole of ancient history where migrant motives are discussed in any detail, though C. Holleran, 'Migration and the urban economy of Rome', in C. Holleran and A. Pudsey, eds., Demography and the Graeco-Roman World (Cambridge 2011), 155-180, at 161 n. 35 later poured cold water over the importance of Augustine's remarks by pointing to the highly individualized nature of such motives. B.D. Shaw, 'Challenging Braudel: a new vision of the Mediterranean', Journal of Roman Archaeology 14 (2001), 424 in a discussion of Horden and Purcell's The Corrupting Sea contrasted Augustine's movements to those of peasants who would never leave their own territory. A. Zerbini, 'Human mobility in the Roman Near East: patterns and motives', in L. de Ligt and L.E. Tacoma, eds., Migration and Mobility in the Early Roman Empire (Leiden 2016), 326 n. 73 used Monica's case as an example of the difficulties in determining the nature of migration from the burial record alone. R.A. Tybout, 'Dead men walking: the repatriation of mortal remains', in L. de Ligt and L.E. Tacoma, eds., Migration and Mobility in the Early Roman Empire (Leiden 2016), 390-437 at 411-412 has contrasted Monica's wish not to be buried at home to the normal practice to transport the remains of people who died elsewhere back home. All these observations are useful, but they are little more than stray remarks, often confined to footnotes. See also the paper of Carucci in this volume.

40 P. Brown, Augustine of Hippo. A Biography (Berkeley and Los Angeles 1967), 156: Augustine "is obsessed by the need to understand what had really happened to him in the distant past." 
Although it is tempting to take the evidence for Augustine's migration patterns simply at face value, the Confessiones should be understood in its own literary context. It is in many respects an idiosyncratic work. Notwithstanding Ciceronean and Virgilean echoes, it operates at least partly outside classical literary conventions. Paradoxical though it may sound, it can be regarded both as the first real autobiography in world history and as a work that does not conform to the requirements of the genre. ${ }^{41} \mathrm{It}$ is highly selective in what it presents and what it does not. ${ }^{42}$

The fact that Augustine presents his life story in the light of his subsequent conversion has consequences for the way migration is portrayed in the Confessiones. Mental restlessness, social ambition and sexual longing (an aspect not always discussed but figuring prominently $)^{43}$ are linked to moving around. Aimless wandering (intellectually and spatially) is contrasted with the serenity obtained with conversion to the true religion and deep knowledge of the omnipresence of God. It is no coincidence that after his conversion Augustine returns to Africa and settles down. In the remainder of the narrative of the Confessiones, outer journeys in the real world are substituted by philosophical and religious introspection. He has found rest in God, and has finally arrived home.

There is some reality to the contrast between worldly movements and Christian sedentary life that structures the Confessiones: after his conversion Augustine would not leave North Africa any more and spent most of the rest of his life as bishop of Hippo. He repeatedly expressed reluctance to leave his circle of friends and dependents. ${ }^{44}$ But to describe Augustine's newly found Christian world as sedentary would be seriously misleading. In fact, we know

41 Brown 1967, op. cit. (n. 40), 158-181, emphasizing at 160 "the astounding novelty of the book", and stating at 28 that "no book undermines with such great artistry the assumptions of conventional biography."

42 At a concrete level, this feature is best known from the imbalances in the space devoted to the members of his direct family: his father Patricius receives passing references, his mother Monica plays a central role, while the existence of at least one brother and perhaps two sisters is not mentioned at all and has to be inferred from other works-see Brown 1967, op. cit. (n. 40), 29. For his concubine and their son, see below.

43 Conversion for Augustine implied sexual asceticism; note that in his conversion narrative this was the final and in many ways most difficult hurdle to be taken. See P. Brown, The Body and Society. Men, Women and Sexual Renunciation in Early Christianity (New York 1988), 387-395 for the context.

44 Ep. 10.1-2 (to Nebridius, AD 389). Later in life, he would also point to his advanced age as an impediment to travel. See O. Perler, 'Les voyages de S. Augustin', Recherches augustiniennes 1 (1958) 5-7, on Ep. 269 (to Nobilius, AD 429-430). 
that Augustine as bishop of Hippo travelled quite a bit, both in his see and further away, in particular to attend a large number of church councils at Carthage. Although with one exception, a trip to Caesarea in Mauretania, ${ }^{45}$ the distances covered by these voyages were more limited than previously, the number of such trips was much larger than before his conversion. ${ }^{46}$ It is also important to realise that when Augustine, around the age of 43 in C.397 AD, wrote the Confessiones and entered the dark recesses of his innermost thoughts, he was at the same time extremely busy as bishop and community leader, receiving dozens of guests when he was not himself away. ${ }^{47} \mathrm{It}$ is an aspect of his life that is passed over in silence in the Confessiones.

Notwithstanding its highly artificial character, the contrast between worldly movement and Christian serenity that structures the Confessiones is of great help for the present purposes. It is precisely because Augustine equated his previous wanderings in the world with his mental restlessness that he described them in relatively great detail. There are several elements in Augustine's and Monica's migration history that are worthy of note, some of them not documented elsewhere. ${ }^{48}$

We may begin with the bare facts of Augustine's movements. Although there are the usual quibbles over chronological details, the outline is not in doubt. ${ }^{49}$ Augustine was born in the small town of Thagaste in AD 354. At some stage during his youth, around $365^{-366}$, when he was about 12 years old, he left his parental home and moved from Thagaste to neighbouring Madauros for

45 See Perler 1958, op. cit. (n. 44), 17 and 25, dating the trip to Sept. AD 418. The distance from Carthage would be over a 1,00o kilometres.

46 Perler 1958, op. cit. (n. 44) 10-20 for a very long list; see also S. Guédon, Voyager dans l'Afrique romaine (Paris 2010) annexe 21, aptly observing "[i]l n'y a pratiquement pas une année (...) sans qu'Augustin ne parte sur les routes africaines une partie des douze mois" (43).

47 Brown 1967, op. cit. (n. 40), 200.

48 My enquiry is directed at those elements that are of importance for migration; the practicalities of travel which were a major interest of Perler 1958, op. cit. (n. 44) and to some extent also of Guédon 2010, op. cit. (n. 46) are left out of consideration (the Confessiones is remarkably poor on these anyway). I base myself exclusively on the Confessiones, leaving other works by Augustine (notably the Contra Academicos and the later letters), by his biographer Posidius and works of others out of consideration. And I confine myself to the secular part of Augustine's whereabouts, up to and including his return to North Africa from Italy.

49 What follows is based on O. Perler and J.-L. Maier, Les voyages de saint Augustin (Paris 1969). 
educational purposes. ${ }^{50}$ After a year or two, he moved back to Thagaste, where he spent what we would call a gap year which allowed his father to save money for further study in Carthage. ${ }^{11}$ By the end of autumn in 370 he went to Carthage, and would spend some five years there. ${ }^{52}$ During this period, in or around 371, his father died. After Augustine's stay in Carthage, he went back to Thagaste in 375 to teach for a short period (a year or so). ${ }^{53}$ In 376 he took up a paid position as a teacher in Carthage, where he worked for some six to seven years. ${ }^{54}$ From Carthage he moved to Rome, where he set up his own school. ${ }^{55} \mathrm{He}$ had left his mother Monica behind, but she followed shortly afterwards. ${ }^{56}$ He then successfully applied to become rhetor in Milan, where the emperor resided. ${ }^{57}$ Again, his mother soon followed him. In Milan he converted to Christianity, which led him to renounce his position and terminate an engagement with a young girl from the local Milanese aristocracy. For a brief period, he and his mother moved to nearby Cassiciacum, then they moved back to Milan for his baptism, ${ }^{58}$ and after this they started on the journey homewards. ${ }^{59}$ On the way back home, at Ostia, Monica died, and was buried there. ${ }^{60}$ Augustine stayed for a brief period in Rome and then went back home to Thagaste via Carthage. Shortly afterwards he went to Hippo, as a priest, later to become bishop, where he would hold the see for the rest of his long life.

One of the most noteworthy aspects of Augustine's mobility is its step-wise character. Augustine reached Milan from his home-town Thagaste in several stages. Most of these stages entailed stays of several years. During the African part of his itinerary he also occasionally returned back home, so his movements were not completely linear either. It is noticeable that at no point in time does his change of domicile appear to be intended as permanent. That is to say, that his stays could become permanent always remained a possibility, but it was never a certainty. To be sure, it seems likely that if Augustine had not converted to Christianity he would have stayed in Milan; he had reached the pinnacle of his career and was preparing for marriage with a local girl. But what

$50 \quad$ Aug. Conf. 2.3.5. Maudauros was c. $20 \mathrm{~km}$ away from Thagaste.

51 Aug. Conf. 2.3.5, the return home is to be dated before 13-11-369.

$5^{2}$ Aug. Conf. 3.1.1, cf. 2.3.5. Carthage was almost $250 \mathrm{~km}$ away from Thagaste.

53 Aug. Conf. 4.4.7.

54 Aug. Conf. 4.7.12.

55 Aug. Conf. 5.8.14; 5.12.22.

56 Aug. Conf. 6.1.1.

57 Aug. Conf. 5.13.23, cf. 5.12.22.

$5^{8}$ Aug. Conf. 9.3.5-9.6.14.

59 Aug. Conf. 9.8.17; 9.10.23.

$60 \quad$ Aug. Conf. 9.11.28. 
would he have done had he not obtained his appointment in Milan? Would he have stayed in Rome, despite his negative appreciation of the students there?

The greatest importance of Augustine's mobility is for the idea that migration in the Roman world was dominated by young adult males. The Confessiones both does and does not support the model of migration by young adult males. It does uphold the model in the sense that it is clear that at each step it was Augustine who moved. Initially, when Augustine was a student, his moves were embedded in family considerations. The role of the father (and mother) in the decisions about schooling is clear; Patricius is clearly the one who formulates the ambitions for his son. ${ }^{61}$ Later in his life, when Augustine became a teacher, his family recedes into the background; Patricius is dead, and his mother Monica is following Augustine rather than making decisions for him (though she does not spare him her opinions). It is also noticeable that the individual decision-making by Augustine is embedded in discussions with friends.

The narrative is also interesting because it demonstrates how marriage can function as the point of settling down, both literally and figuratively. It also shows the importance of return migration. In fact, the story of the renunciation of his marriage with a young Milanese girl demonstrates nicely two major options of young male migrants in a new city: marry and settle, or return home. Augustine first considered the former, and after his conversion decided on the latter.

We thus clearly have to do with a young adult male migrant. But Augustine was not alone when he moved through the Roman world.

In the first place, his mother Monica followed Augustine closely. When he went from Carthage to Rome he left Monica behind, in a famous scene full of Vergilian echoes. ${ }^{62}$ But the narrative implies that Monica had previously moved from Thagaste to Carthage. It seems likely that the cause was the death of her husband. After Augustine moved to Rome, his mother followed suit. When Augustine moved to Milan, she again followed him somewhat later. Monica's case probably exemplifies what happened more often in the case when women became widows: they moved in with their children (and most likely with their sons). Yet Monica's case is also interesting because she did travel on her own, and seems to have made her own decisions. In fact, the dramatic scene at Carthage when Monica was left behind-reminiscent of the way that Aeneas left Dido-is presented as a conflict of opinions; Monica as a widow retained her independence.

\footnotetext{
61 Aug. Conf. 2.3.5.

62 Aug. Conf. 5.8.15; cf. 6.1.1.
} 
When Augustine moved around, he did so as an unmarried male. In that sense there was no family migration. However, he did have a concubine. This concubine has acquired some fame as the anonymous attachment to Augustine that figures surprisingly little in the Confessiones. ${ }^{63}$ She appears mainly when he recounts how she had to leave and returned to her native Carthage when his marriage plans were announced in Milan:

avulsa a latere meo tamquam impedimento coniugii cum qua cubare solitus eram, cor, ubi adhaerebat, concisum et vulneratum mihi erat et trahebat sanguinem. et illa in Africam redierat, vovens tibi alium se virum nescituram, relicto apud me naturali ex illa filio meo.

That woman with whom I used to share my bed was torn from my side, on the grounds that she stood in the way of my marriage. My heart, which was so attached to her, was broken and pierced, leaving a trail of blood. She returned to Africa vowing to you that she would never have another man. She left behind with me my son she had borne to me. ${ }^{64}$

The fact that she vowed to continue her life as an univira is very interesting, as in doing so she appropriated concepts normally associated with widowed women in full Roman marriage. But even more remarkable is that from some other casual remarks we learn that Augustine had lived with her for at least a decade. ${ }^{65}$ They also had a son, Adeodatus, who also appears only a few times in the book. ${ }^{66}$ The implication must be that Augustine had moved together with this small family from his stay in Carthage onwards, a family which remains otherwise completely invisible. This family was too unimportant (equal to slaves, one would say), or too embarrassing, to be mentioned. ${ }^{67}$

In modern discussions of Augustine's concubine, it is emphasized that despite Augustine's disparaging remarks, there was for young adult males nothing abnormal about having such a companion. ${ }^{68}$ Although it would be

\footnotetext{
63 Brown 1967, op. cit. (n. 40), 61-63; 88-89.

64 Aug. Conf. 6.15.25 (transl. C.J.-B. Hammond 2014).

65 Aug. Conf. 4.2.2.

66 Aug. Conf. 4.2.2; 9.6.14; 9.12.29.

67 It is possible that the concubine and the son travelled around with Monica rather than with Augustine himself, but this does not alter the fundamental fact that they are barely referred to in the narrative. The contrast with Monica is marked.
}

68 Note that her repudiation had nothing to do with Augustine's conversion to Christianity; in fact, as the passage implies, the concubine was already a Christian herself. For the normality of the practice, see B.D. Shaw, "The family in Late Antiquity: the experience of 
rash indeed to assume that all young men who appear as sole travellers in our epigraphic sources did so, the corollary of the argument that concubines were a regular feature in the Roman world might imply that more migrants travelled around with otherwise invisible companions. ${ }^{69}$

The last element meriting discussion is the way death structures what we know about migration, and this brings us back to Monica. The fact Monica died in Ostia was coincidental in the sense that neither she nor Augustine had any desire to stay for longer in Ostia. Monica had lived for prolonged periods in Thagaste, in Carthage, in Rome, in Milan and also for a short time in Cassiciacum, but she was buried in none of these places. Without the Confessiones we would not have any idea why and how this female migrant from Thagaste ended up in Ostia. In fact, we would not even have known that she was a migrant; Monica's epitaph, a commemorative epigram written long after her death, does not refer to her mobility at all. ${ }^{70}$ Moreover, Monica had initially made arrangements to be buried in Thagaste in the tomb of her husband Patricius, but only on her deathbed changed her mind. ${ }^{71}$ Her story is of real interest, as it makes clear that the norm was to be buried in home grounds, and that the ashes or bones had to be transported back if people died elsewhere. In this case, as Augustine was accompanying her, that could have been easily arranged. Monica decided otherwise, and opted for burial at Ostia. If she had been interred alongside her husband in Thagaste, who would have known from her grave that she had seen quite a bit of the world at all?

A fundamental and obvious problem remains: how representative are the Confessiones? Obviously, Augustine and Monica are not representative of every migrant who moved in the Roman empire. We are dealing with members of the elite, though it remains equally important to emphasise that they belonged to the lower ranks of a local elite of a rather insignificant town. ${ }^{72}$ The problem

Augustine', Past \& Present 115 (1987), 3-51, at 16 on Augustine's later sermons against the practice. Note further that Augustine actually took a second concubine after the first had been sent away, because he had to wait to enter the marriage as the prospective bride was not yet of legal age; see Aug. Conf. 6.15.25 with Shaw, 45 .

69 As Werner Eck pointed out in the discussion during the conference in Rome, new recruits and soldiers may have travelled around in similar fashion.

70 D. Boin, 'Late antique Ostia and a campaign for pious tourism: epitaphs for bishop Cyriacus and Monica', Journal of Roman Studies 100 (2010), 195-208.

71 Aug. Conf. 9.11.28, with Tybout 2016, op. cit. (n. 39).

72 As Shaw 1987, op. cit. (n. 68), 8 has argued convincingly against Brown 1967, op. cit. (n. 40), 21 concerning Augustine's claims in Aug. Conf. 2.3.5 that Patricius was of modest means, Augustine's family was certainly not poor, but belonged to a stratum of landowners with moderate wealth. 
is aggravated by the fact that the work itself invites to be read as a highly personal and spiritual journey. There also can be little doubt that Augustine was an extremely charismatic and towering figure-in many respects he was (and remains) larger than life. Not everyone will have had Augustine's immense talents, not everyone in this period will have been so desperately in search of religious truth. Nor would every young Roman have had a mother as strongwilled as Monica (or so one may hope).

\section{$5 \quad$ Anything Goes?}

In consequence, we have ended up with three different types of sources, all of which tell a rather different story about Roman migration. It seems difficult if not impossible to move out of this blind alley.

Obviously, more research could be done, in all three cases. More isotopic research could be done on the remaining skeletons of Isola Sacra, also by using different types of stable isotopes, and surely the discussion of third molars could be improved. The epitaphs and tombs of the Isola Sacra necropolis could be subjected to more rigorous scrutiny, and in particular the areas outside of the 100-tomb area could be taken into account (which would roughly double the amount of material). Also, more research could be done on Augustine, extending the analysis beyond the Confessiones, and taking other persons that circled around him into account as well. In all three cases we would be sure to gain a deeper understanding.

However, it can be doubted that further research will bridge the gaps between the three types of sources. In fact, it may be suspected that they will only be deepened. What we know about the context and representativeness of the three cases suggests as much. The isotopic findings are roughly in line with those from elsewhere. The Isola Sacra epigraphy presents a picture that is similar to that of many other Roman necropoleis. The movements of Augustine can be paralleled by those of many other intellectuals, also in the earlier period. More research may further understanding but is unlikely to solve the problem of the discrepancies.

Attempts to argue that the three cases somehow do not concern the same population seem forced. Economy of hypothesis suggests that the three types of sources cover roughly the same people in the same place. And even if they do not, it would not fundamentally alter the nature of the problem.

There is a possibility that the problems are particularly large because Ostia was a harbour city. Arguably, harbours not only attracted many migrants, but the temporary nature of migration may also have led, in a sense, to distortions 
and fluidity in recording practices. One may also point to the fact that epigraphic habits could differ from place to place. ${ }^{73}$ These are certainly valid points. It should be realised, however, that for the city of Rome a very similar case could be made to the one for Isola Sacra. Although its migrant epigraphy is infinitely richer, the numbers dwindle in comparison to the full epigraphic record of the city. ${ }^{74}$ The published isotopic analyses also do not square well with the epigraphic evidence. ${ }^{75}$

Be that as it may, there is no reason to privilege any of the three types of sources: all should be seen as empirical evidence, and all are marred by imperfections. Isotopic evidence clearly has the potential to uncover mobility that remains otherwise unmarked in the burial record, but its evidence is less direct and hard than it seems. Epigraphic evidence can show places of origin in a way which isotopic evidence will probably never be able to do, but we are dependent on the willingness of the commemorators to provide such information. A literary work like the Confessiones captures the dynamism that is so crucial to our understanding of mobility much better than the static snapshots from the burial record, but one might easily argue that eine Quelle ist keine Quelle. All three have so many inbuilt weaknesses that all three could logically be discarded on similar grounds.

It is possible to stop the argument here, and simply leave the inconsistencies for what they are. This could even be defended on philosophical grounds. It would be possible to embrace the epistemological anarchy advocated 40 years ago by Paul Feyerabend, who argued against the 'consistency condition' in the humanities and famously and polemically stated that "anything goes."76 But this also seems unsatisfactory, if not intellectually irresponsible. Such a position would come close to a post-modernist perspective on history that is ultimately inimical to scholarly research. In the end there is no choice but to try to reconcile the findings, or at least to use the combination of the findings to eliminate less likely inferences. ${ }^{77}$ In a discussion of a different subject, the

73 These points were brought up in the discussion in Rome. For variation within the epigraphic record, see Tacoma and Tybout 2016, op. cit. (n. 1).

74 The migrant epigraphy is analysed in full in D. Noy, Foreigners at Rome. Citizens and Strangers (London 2000).

75 Killgrove 2010 op. cit. (n. 5).

76 P. Feyerabend, Against Method. Outline of an Anarchistic Theory of Knowledge (London 1975), 28: "there is only one principle that can be defended under all circumstances (...): anything goes" (emphasis in the original).

I owe the latter point to Jeremia Pelgrom; the difference between the two may be conceptualised as a positive attempt at ironing out inconsistencies versus a negative process of elimination—-the latter is attractive because it is less forced. 
historiography of ancient slavery, Niall McKeown approvingly quotes Georg Iggers, who wrote that

There is $(. .$.$) a difference between a theory that denies any claim to real-$ ity in historical accounts and a historiography that is fully conscious of the complexity of historical knowledge but still assumes that real people had real thoughts and feelings that led to real actions that, within limits, can be known and reconstructed. ${ }^{78}$

This belief in a historical reality that not only exists, but that also can be known within limits, could be backed up by the idea that there are various types of historical truth, or, in plain language, that each type of source tells a different part of the same story.

So how would such a story run? How can the findings be reconciled?

I believe that the percentage provided by the study of isotopes is in the right order, that is, that in Ostia roughly one-third of the population was born elsewhere, also because it corresponds with what we think we know about harbour cities. But, as the whereabouts of Augustine and Monica suggest, much migration was stepwise and many stays were temporary. Permanent resettlement was just one option among many others, and few free people who moved would have known at the outset that they were to resettle forever. Given this lack of permanence, where people were buried was to some extent dependent on chance. The lack of permanency may also explain to some extent why migrant origins were not always marked on epitaphs - though there is no direct link between permanency and inscribing migrant status. The prevalence of slaves in the epigraphy and tombs of Isola Sacra points to the issue of social and legal status. Surely some of the immigrants were brought to Ostia as slaves. This would go some way to explain the presence of 'children' in the isotopic evidence. For the younger part of the migrant population, slavery seems a better working hypothesis than family migration. But it does not explain the presence of women and children or sub-adults completely. Both epigraphy and the Confessiones suggest that the model of single male migrant was dominant

78 G. Iggers, Historiography in the Twentieth Century: From Scientific Objectivity to the Postmodern Challenge (Middleton 1997), 119, in a chapter significantly called "The "linguistic turn": the end of history as a scholarly discipline?', quoted by N. McKeown, The Invention of Ancient Slavery? (London 2007), 9. Note that the context of McKeown's extremely interesting discussion is slightly different from mine: he discusses competing but internally coherent interpretations of the same source, whereas here the issue is what to do with conflicting sources used to analyse the same historical reality. 
as a societal norm. Immigrants were supposed to be young adult males. At the same time, Augustine's case shows that some may have been travelling with families of concubines and sons, followed by slaves and, some, though no doubt fewer, will have been followed by widowed mothers.

Whether such a reconstruction is plausible is for others to decide. For the present purposes, the point is a different one. In offering such an interpretation, the room for manoeuvre is not infinite, but there is still considerable leeway. And that gives reason to pause. Not only do we have to take all available sources into account, as we no doubt all aim to do, but before we start to do so and before we start to create a coherent narrative, we would do well to analyse the inconsistencies first.

Leiden, November 2015 